\title{
IDEA DEMOKRACJI W PRZEKSZTALCENIACH USTROJOWYCH SAMORZĄDU TERYTORIALNEGO
}

Celem artykułu jest ukazanie idei demokracji jako podstawowego warunku urzeczywistnienia decentralizacji i samorządu terytorialnego, a także zagrożeń, które towarzyszą procesom demokratyzacji i uświadamiają potrzebę ich ochrony ${ }^{1}$.

Demokracja pojmowana zarazem jako wartość i zasada współtworzy wraz z zasadą wolności i zasadą państwa prawnego jeden z podstawowych standardów aksjologicznych i ustrojowych we współczesnej Europie ${ }^{2}$. Jednak próby określenia demokracji podejmowane w nauce poszczególnych państw ukazuja różne postacie, w jakich się ona przejawia; w następstwie mnożą się definicje zasady demokracji i samego państwa demokratycznego. Poszukiwanie definicji uniwersalnej, powszechnie akceptowanej nie wydaje się konieczne, gdyż w perspektywie porównawczej dostrzega się rozliczne i zmienne uwarunkowania, w jakich funkcjonuje demokracja stosownie do urzeczywistnianej konstytucyjnej koncepcji ustrojowej danego państwa ${ }^{3}$. Różnorodność ujęć nie osłabia siły oddziaływania idei demokracji, a zwłaszcza jej siły inspiracji. Jak pisze Georges Burdeau: „Demokracja jest dzisiaj filozofia, sposobem życia, religia i, nieomal dodatkowo, forma rządu”. Tak szerokie znaczenie prowadzi do uznania, że w istocie demokracja jest idea potrzebną ludziom, gdy sytuują w niej swą nadzieję lepszego życia ${ }^{4}$. W państwie prawnym demokracja chroni wszystkie prawa i wolności jednostki wiązane z liberalizmem politycznym. „Utożsamianie demokracji z demokracją liberalną jest tak powszechne, że często wydaje się, że jest przyjmowane jako robocze założenie" ${ }^{5}$. Podstawowe wolności liberalne są wyprowadzane z koncepcji wolnych wyborów, ich warunkiem sa m.in. wolność myśli i słowa, swoboda zrzeszania się, prawo do ochrony przed ingerencją władzy w sferę prywatną. Hubert Izdebski podkreśla, że określenie

${ }^{1}$ W ujęciu bardziej szczegółowym: rozważania koncentrują się na swoistym refleksie idei demokracji znajdującym wyraz w przeświadczeniu łączącym jej niepodważalne walory z koniecznością stałego przeciwdziałania jej immanentnym słabościom.

${ }^{2}$ H. Izdebski, Fundamenty wspótczesnych państw, Warszawa 2007, s. 74.

${ }_{3}$ B. Banaszak, Porównawcze prawo konstytucyjne współczesnych państw demokratycznych, Kraków 2004, s. 289.

${ }^{4}$ G. Burdeau, La démocratie, Paris 1956, s. 9.

${ }_{5}$ O. Raban, Racjonalizacja polityki: o zwiazku między demokracja a rzadami prawa, „Ruch Prawniczy, Ekonomiczny i Socjologiczny” 76, 2014, z. 4, s. 23. 
„demokracja liberalna” nie odwołuje się do ideologii liberalizmu. Jest to wskazanie pierwotnego źródła demokracji liberalnej - nurtu filozoficznego w okresie oświecenia, który przyniósł postulaty walki o wolność człowieka ${ }^{6}$.

Zarazem jednak tak często spotykane zestawianie demokracji i liberalizmu nie wskazuje prostej („linearnej”, jak pisze Norberto Bobbio) współzależności. Demokracja jest bowiem jedną z form rządzenia, „w której władza znajduje się w rękach nie jednostki bądź wąskiej grupy, lecz wszystkich, a ściślej większości”, jest więc przeciwstawiana rządom autokratycznym (monarchii czy oligarchii). Z kolei liberalizm odnosi się do koncepcji państwa, „w myśl której ma ono ograniczony zakres funkcji i władzy" (państwo-minimum) i jest przeciwstawiane zarówno państwu absolutnemu, jak i państwu o rozbudowanej, dominującej funkcji socjalnej ${ }^{7}$. Złożoność relacji Bobbio dostrzega w tym, że państwo stosujące demokratyczne zasady sprawowania władzy nie staje się w sposób konieczny państwem liberalnym; nie zawsze też państwo liberalne było demokratyczne ${ }^{8}$.

Przyjmując perspektywę historyczna, Bobbio tworzy schemat, który trudno byłoby tu pominąć, ilustrujący trojakie stosunki między liberalizmem a demokracją. Po pierwsze, sa to stosunki współbieżne, czyli równocześnie możliwe (niewykluczające się - jak w podanym wyżej przykładzie); po drugie, stosunki antytetyczne (relacja wykluczenia), gdy „demokracja doprowadzona do ostatecznych konsekwencji niszczy w końcu państwo liberalne"9; po trzecie, stosunki konieczności, gdy jedynie demokracja jest w stanie urzeczywistnić liberalne ideały, państwo liberalne zaś - zapewnić stosowanie zasad demokracji ${ }^{10}$.

Demokracja - demokracja liberalna znajduje podstawę filozoficzną w doktrynie praw człowieka wypracowanej przez szkołę prawa natury. Państwo, a ściślej ci, którzy rządza, „muszą uszanować te prawa, nie naruszając ich, a także być ich rękojmią na wypadek, gdyby inni chcieli je naruszyć” ${ }^{11}$. Na tej podstawie oparta została także konstrukcja podmiotowości prawnej społeczności lokalnych, wywodzących swe prawa do zajmowanego terytorium z wielowiekowej tradycji ${ }^{12}$. Wkrótce po Deklaracji praw człowieka i obywatela z 26 sierpnia 1789 r. rewolucja francuska, „wychodząc z teorii wolnościowej, skłonna była te same prawa, które przyznawała teoretycznie jednostkom, przyznać $\mathrm{w}$ teorii także zrzeszeniom ludzkim pojętym, jako jedna ca-

${ }^{6}$ H. Izdebski, op. cit., s. 75 .

${ }^{7}$ N. Bobbio, Liberalizm i demokracja, Kraków 1998, s. 5.

8 „Historycznie urzeczywistniało się wręcz w społeczeństwach, w których uczestnictwo w rządzeniu ograniczało się jedynie do klas posiadajacych", ibidem.

${ }^{9}$ Także gdy demokracja „może w pełni ziścić się tylko w państwie socjalnym (opiekuńczym)”, dalekim od ideału państwa-minimum, ibidem, s. 35.

${ }^{10}$ Ibidem, s. 36. Potwierdza ten pogląd J. H. Hallowell: „[...] istnieje ścisły związek między liberalizmem a demokracją [...]. Mają one swe wspólne źródła w XVII w., odkąd liberalizm jako filozofia polityczna i społeczna wspierał demokratyczne formy rządzenia" (idem, Moralne podstawy demokracji, Warszawa 1993, s. 68).

${ }^{11}$ N. Bobbio, op. cit., s. 7. Zob także W. Osiatyński, Prawa człowieka i ich granice, Kraków 2011, s. 127.

${ }_{12}$ Znakomity autor francuski Jean Rivero tak określi ich pozycję ustrojowa w swym współczesnym podręczniku prawa administracyjnego: „ensembles humains préexistants dans son territorie [...] dotées d'une vie juridique propre, Droit administratif' (Paris 1983, s. 318). 
łość, a więc gminom. [...] przyniosła ona w swem zaraniu nową ideę, która stała się podstawą kodyfikacji ustaw gminnych innych państw”, pisał Jerzy Panejko ${ }^{13}$. Samorzą ustanowiony w liberalnej fazie rewolucji uznawano za rozwiązanie racjonalne. „Liberałowie dobrze dostrzegali różnorodność, pluralizm, wielobarwność świata, próby jego uniformizacji uważali za nierozsąne i zabójcze"14. Dzieło rewolucji było jednak uwikłane w sprzeczności, które musiały doprowadzić do kryzysu. Był to kryzys nie tylko idei, lecz także państwa. Uwolniono się od despoty, ale wszystko co było dlań najistotniejsze - pozostało; ,jego rządy się skończyły, ale administracja żyła dalej i ilekroć odtąd chciano obalić władzę absolutna, poprzestawano na umieszczeniu głowy Wolności na niewolniczym tułowiu"15. W obawie przed scentralizowana administracją królewską we wszystkich departamentach, gminach, dystryktach powierzono władzę organom pochodzącym z wyborów, każdy okręg stał się mała republika, swobodnie administrujacca i uwolnioną od ingerencji władzy centralnej. Jest to „decentralizacja rozpasana” (décentralisation échevelée) pisze Jean-Jacques Chevallier i przytacza wypowiedź Emmanuela Sieyèsa: „44000 gmin odnosiło się do władzy wykonawczej raczej jak do wroga niż centrum łączącego"16. Nastapił paraliż władzy centralnej; następcy Konstytuanty byli zmuszeni podnieść z ruin i odrestaurować centralizację - „z wnętrza narodu, który dopiero co obalił monarchię, wyłoniła się nagle władza szersza, bardziej pedantyczna i absolutna niż ta, jaka niegdyś przysługiwała naszym królom"17.

Centralizacja napoleońska uwolniła zatem władzę od samorządowych kłopotów; burbońska restauracja, a następnie Ludwik Napoleon u progu II Cesarstwa podtrzymały tendencje centralistyczne (aczkolwiek w formie nieco złagodzonej, zapowiadając ograniczenie urzędniczego formalizmu - co opacznie określono jako decentralizację $\left.{ }^{18}\right)$. Centralizacja stała się przedmiotem politycznej, a także teoretycznej refleksji wówczas, gdy pojawiła się dla niej ideowa, polityczna, a wreszcie prawna alternatywa - decentralizacja. W drugiej i trzeciej dekadzie XIX w. nasiliła się krytyka centralizmu, „liberałowie stawali się głównymi przeciwnikami ustrojowego spadku wielkiego cesarza”19. W dyskusji, pod wpływem dzieła Alexisa de Tocqueville’a O demokracji $w$ Ameryce (t. 1 został opublikowany w 1835 r.), pojawił się podstawowy dylemat liberali-

${ }^{13}$ J. Panejko, Geneza i podstawy samorzqdu europejskiego, Paryż 1926, s. 21 (reprint Wyd. „Przemiany”, Warszawa 1990). Była to rzeczywiście nowa idea. Dopiero w okresie rewolucji „obraz wolności pojawił się w umysłach Francuzów i z każdym dniem wydawał im się coraz bardziej pociagający [...]. Prowincje zaczynają przejawiać chęć samodzielnego administrowania swoimi sprawami. Pogląd, że cały lud ma prawo do udziału w rządach, ostatecznie przenika do umysłów”, A. de Tocqueville, Dawny ustrój i rewolucja, Kraków 1994, s. 178.

14 J. Baszkiewicz, Wtadza, Wrocław 1999, s. 101.

15 A. de Tocqueville, Dawny ustrój..., s. 216.

${ }_{16}$ J.-J. Chevallier, Histoire des institutions politiques de la France modern (1789-1945), Paris 1958 , s. 130.

17 A. de Tocqueville, Dawny ustrój..., s. 215.

18 O. Diederichs, I. Luben, La déconcentration, Seria: Que-sais-je, Paris 1995, s. 12.

${ }_{19}$ H. Izdebski, Problemy decentralizacji administracji we Francji $w$ XIX wieku, „Czasopismo Prawno-Historyczne" 28, 1976, z. 2, s. 163; F. Burdeau, Histoire de l'administration française. Du 18 e au 20e siècle, Paris 1994, s. 191. 
zmu: zachowania wolności w warunkach równości ${ }^{20}$. Demokracja obiecuje wolność, lecz opiera się na równości. Równość w demokracji oznacza, że wszyscy podlegają tym samym regułom, a to sprzyja jednolitości i centralizacji rządu - słuszne jest to, czego chce większość; większość ma więc prawo pełnej swobody rządzenia. „W konsekwencji jeśli rząd wiernie wyraża wolę większości, ludzie godzą się potulnie z jego nieustannym umacnianiem"21. Bobbio traktuje wolność i równość (w ich najszerszych znaczeniach, rozszerzonych na sferę ekonomiczna) jako wartości przeciwstawne: „nie można bowiem urzeczywistnić jednej bez znacznego ograniczenia drugiej” - wyrastają z głęboko z różnych koncepcji człowieka i społeczeństwa. Koncepcja bliska liberałom „jest indywidualistyczna, pluralistyczna i aprobujacca konflikt”, natomiast egalitarystyczna jest „całościująca, harmonizująca i monistyczna”. Stąd pojawia się postulat równości w wolności, „znaczy ona tyle, że każdemu należy się tyle wolności, ile da się pogodzić z cudza"22.

Stopniowo, w toku ewolucji ustrojowej państwa, wśród wielu napięć i w swoistej dwubiegunowości (przekonanie o konieczności centralizacji kierowania sprawami ogólnymi państwa i o odrębności prowadzenia spraw lokalnych) kształtowało się pojęcie decentralizacji; umacniało się przekonanie, że demokracja jest jej warunkiem, a samorząd formą instytucjonalną udziału obywateli w rządzeniu, służąca budowaniu demokracji od dołu ${ }^{23}$.

W sekwencji pojęć: demokracja (jako idea rządzenia, według której „władza znajduje się w rękach nie jednostki bądź wąskiej grupy, lecz wszystkich, a ściśslej - większości” ${ }^{24}$ ) - decentralizacja (jako zasada określajacca ustrój władzy wykonawczej) - samorzą terytorialny (jako forma instytucjonalna administracji lokalnej) z czasem pojawiło się kolejne ogniwo uwydatniające ideowy aspekt samorządu - demokracja lokalna. Pojęcie demokracji lokalnej jest uogólnieniem walorów politycznych i społecznych samorządu lokalnego, dostrzeganych w mocniej lub słabiej uświadamianej perspektywie historycznej i porównawczej - i najczęściej w połączeniu z procesem przemian ustrojowych: jako pozytywny efekt tych przemian lub jako cel (wartość), o którą należy zabiegać w projektowanych reformach. Zakres pojęcia jest konstruowany wokół kilku ustalonych elementów definiujących (np. wybór organów, względna sa-

\footnotetext{
${ }^{20}$ J. Baszkiewicz, Wstep, w: A. de Tocqueville, O demokracji $w$ Ameryce, Warszawa 1976, s. 13 .

${ }^{21}$ Ibidem, s. 15. Zarazem „[...] wolność stanowi jedno z najważniejszych pojęć współczesnego konstytucjonalizmu i współczesnej myśli politycznej”, pisze H. Izdebski, omawiając filozoficzne i prawnicze koncepcje wolności i równości, ibidem, Fundamenty..., s. 33 i n. oraz s. 76 i n.

22 N. Bobbio, op. cit., s. 25.

${ }^{23}$ B. Banaszak, op. cit., s. 566. Tak można pojmować relację między pojęciem demokracji a pojęciem samorządu lokalnego wyrażoną w preambule Europejskiej karty samorządu lokalnego: „Biorąc pod uwagę, iż wspólnoty lokalne stanowią jedną z zasadniczych podwalin każdego ustroju demokratycznego [...]", Dz. U. 1994, Nr 124, poz. 607 ze sprost.

${ }^{24}$ N. Bobbio, op. cit., s. 5. Starożytne pojmowanie demokracji implikowało przeciwstawienie rządów ludu rządom jednostki lub nielicznych. Można sądzić, pisze Bobbio, że pomimo upływu wieków i niezliczonych dyskusji, ogólne, deskryptywne znaczenie terminu pozostało niezmienione, „zmieniał się natomiast [...] jego ładunek wartościujący”. Podmiotem władzy pozostaje zawsze „lud” rozumiany jako ogół obywateli władny podejmować zbiorowe decyzje; „zmienił się zakres mniej lub bardziej szeroki - sprawowania tej władzy”, ibidem, s. 20.
} 
modzielność decyzji w sprawach lokalnych), elementy dopełniające są wskazywane zależnie od aktualnych uwarunkowań i preferencji.

Można wyodrębnić różne konteksty, w jakich pojawia się pojęcie demokracji lokalnej. We Francji tak określano (a zarazem pozytywnie oceniano) założenia, przebieg i efekty wielkiej reformy decentralizacyjnej, u której podstaw znalazła się słynna ustawa z 2 marca 1982 r. dotycząca praw i wolności gmin, departamentów i regionów, a także antecedencje tej reformy sięgające ancien régime' $u^{25}$. Tak też niekiedy określa się szeroka płaszczyznę funkcjonowania wspólnot lokalnych ${ }^{26}$. W Polsce określenie to znalazło się w nazwie niezwykle zasłużonej Fundacji Rozwoju Demokracji Lokalnej, było też wielokrotnie powoływane w Raporcie Fundacji i w dyskusji o stanie samorządu terytorialnego w Polsce ${ }^{27}$. Z kolei 25-lecie odrodzenia polskiego samorządu oraz utworzenia Fundacji stało się przedmiotem ważnych konferencji naukowych oraz krytycznych publikacji, w których pojęcie demokracji jest kryterium wyodrębnienia zespołu powiązanych zjawisk podlegających diagnozie, ocenie i, zależnie od oceny - objętych propozycjami zmian. Odwołując się jedynie do wybranych przykładów takiej kwalifikacji teoretycznej, można wskazać artykuł Ireny Lipowicz, majacy charakter syntezy konstruowanej na podstawie klasyfikacji zasad samorządu terytorialnego. Jest w nim m.in. mowa o zasadzie demokracji przedstawicielskiej, która ewoluuje ku wzmocnieniu bezpośredniego udziału mieszkańców w podejmowaniu decyzji, co stało się widoczne w przypadku budżetów obywatelskich. „Z punktu widzenia legitymacji demokratycznej jest to interesujacy podział podstawy działania" ${ }^{28}$. W obszernym eksperckim dwutomowym Raporcie o stanie samorzadności terytorialnej $w$ Polsce ${ }^{29}$ diagnoza oraz propozycje rozwiązań znalazły się w rozdziałach Demokracja samorzadowa. W części diagnostycznej za podstawowe dysfunkcje uznano m.in.: dominację organów wykonawczych nad organami stanowiącymi gmin, powiatów i sej-

${ }_{25}$ Deux cents ans de democratie locale, „Territoires”, septembre 1989, № 300 . W innym kontekście wskazano dynamikę procesu decentralizacji: „demokracja lokalna jest zawsze zadaniem, jest zawsze w budowie”, wypowiedź Ministra Spraw Wewnętrznych 25 października 1989 r. na kongresie Stowarzyszenia Merów Francji, Les collectivités territorials, Les Cahiers Français. La Documentation Française, janvier-février 1989, N²39, s. 79.

${ }^{26}$ „Demokracja lokalna staje się podstawowym elementem spójności narodowej. Jeśli Prefekt dystansuje się prawnie wobec wspólnot zdecentralizowanych, to nie z powodu obojętności, ale zaufania, ponieważ radni lokalni muszą mieć coraz większy udział w sprawach interesu narodowego, który nie musi zawsze zbiegać się z interesami lokalnymi”, P. Bernard, Le Préfet de la République. Le chêne et l'olivier, Paris 1992, s. 39.

27 Samorzad $i$ demokracja lokalna - osiagnięcia, zagrożenia, dylematy. Raport, „Samorząd Terytorialny" 12, 2002, nr 5. Raport nie definiuje demokracji lokalnej. Z treści Raportu wynika, że rozróżnienie wskazane w tytule dotyczy ustroju samorządu (który nie wymaga rewizji) oraz praktyki jego funkcjonowania (która wywołuje istotne zastrzeżenia i rodzi dylematy). Zadziwiające, jak wiele krytycznych uwag zawartych w Raporcie nie tylko zachowało aktualność, ale także wzmocniło swoją wymowę alarmująca.

28 I. Lipowicz, Odrodzenie samorzadu terytorialnego w Polsce w latach 1990-1998-perspektywa administracyjna. Naprawa transformacji ustrojowej, „Samorząd Terytorialny” 25, 2015, nr 3, s. 13.

${ }^{29}$ Narastajace dysfunkcje, zasadnicze dylematy, konieczne działania. Raport o stanie samorzadności terytorialnej w Polsce, t. 1-2, Kraków 2013-2014. 
mikami; odnawianie się reprezentantów samorządowej władzy wykonawczej kosztem autentyczności wyborów; upartyjnienie działalności samorządu terytorialnego; nikłe zaangażowanie obywatelskie w działalność samorządową ${ }^{30}$. W ten sposób został wyodrębniony obszar wymagający racjonalnych zmian nie tylko koniecznych w świetle uwarunkowań społecznych i gospodarczych, lecz także umożliwiających osiągnięcie i utrzymanie się w standardzie samorządności właściwym dla cywilizacji Europy Zachodniej ${ }^{31}$.

Nie jest celem tego opracowania prezentacja trudnych do przecenienia diagnoz i postulatów, istotne jest natomiast pytanie, jakie sa ideologiczne założenia leżące u podstaw dążeń do wzmocnienia (reorganizacji) samorzadu terytorialnego, czy zwłaszcza wartości implikowane w idei demokracji (szczególnie demokracji lokalnej, przedstawicielskiej, samorządowej) dają samoistna gwarancję urzeczywistnienia potrzeb i oczekiwań ludzi, których egzystencja w dużej mierze jest uwarunkowana istnieniem i działaniem samorządu terytorialnego. Czy idea demokracji niesie zagrożenia, które mogą być źródłem dysfunkcji niezależnie od błędów, jakie można popełniać w złożonych procesach zaspokajania zbiorowych potrzeb wspólnoty? ${ }^{32}$

Szukając odpowiedzi na to pytanie, wypada zaczać od nieco zapomnianej, lecz zdecydowanej negacji wartości demokracji Jerzego Panejki. Traktuję ten pogląd jako refleks idei demokracji, ważny dlatego, że jest zawarty w książce, która od wielu lat jest zaliczana do kanonu kształtującego (obok książki Tadeusza Bigo) teoretyczne i operacyjne koncepcje ustrojowe samorządu terytorialnego w Polsce. W ostatnim rozdziale swojej monografii (zatytułowanym Samorzad i demokracja) Panejko przeciwstawia liberalizm, wiążący się z prawami człowieka, demokracji wywodzącej się z doktryny suwerenności narodu. Liberalna „wolność od państwa” zasadniczo różni się od prawa jednostki do „udziału w państwie” i tworzeniu woli suwerennego narodu oraz bezwzględnego poddania się woli większości. „W demokracji rządzi niezorganizowana masa, nie uznająca indywidualności grup lub jednostek, lecz tylko bezwzględną równość wszystkich", pisze Panejko. Istotą samorządu jest natomiast indywidualność i samodzielność. Z tego względu „koliduje idea samorządu z idea demokracji”, jest więc samorzą bliski idei liberalizmu, pozostawiającej sferę działalności grup społecznych odgraniczonych w miarę możności od państwa i uwolnionych od jego kurateli ${ }^{33}$. Idea „suwerenności masy narodu” nieuchronnie prowadzi do centralizacji władzy państwowej i do negacji samorządu, „ponieważ jego natura nie zgadza się z abstrakcyjnym dogmatem demokracji oraz

30 Ibidem, t. 1, s. 28-33, t. 2, s. 27 i n.

31 W krytycznej refleksji o sytuacji samorządu terytorialnego w Polsce jeden z jego twórców pisze: „Wszystko to dowodzi, że chcielibyśmy do Zachodu, ale bez przestrzegania wypracowanych tam mechanizmów i standardów demokratycznych”, J. Stępień, Kształt reaktywowanego samorzqdu terytorialnego w zamierzeniu jego twórców, „Samorząd Terytorialny” 25, 2015, nr 1-2, s. 18; idem, Cywilizacyjny spór o samorzad terytorialny, „Samorząd Terytorialny” 25, 2015, nr 3, s. 17-22.

32 Zbliżone pytania zadaje F. Kjellberg, Zmieniajace się wartości władz lokalnych, w: P. Swianiewicz (red.), Wartości podstawowe samorzqdu terytorialnego i demokracji lokalnej, Warszawa 1997, s. 137 i n.

33 J. Panejko, op. cit., s. 123. 
z jej światem". Panejko zestawia absolutyzm demokratyczny z absolutyzmem monarszym; centralizacja niszczy samorząd, czego przykładem jest Francja ${ }^{34}$. Poglądy Jerzego Panejki opierają się na zdecydowanej krytyce koncepcji umowy społecznej Jana Jakuba Rousseau. Uznając jej triumf w rozwoju idei suwerenności i niezbywalnych praw człowieka, a także „zwycięski pochód” przez rozmaite kraje, Panejko przyznaje, że umocniła pragnienie wolności i przygotowała rewolucje francuska. Zarazem jednak pisze: „[...] suwerenność narodu jest tworem bez formy, gdyż wyklucza wszelkie naturalne ugrupowania, a zastosowana $\mathrm{w}$ praktyce zamienia się $\mathrm{w}$ matematyczny ilościowy majestat, w którym wszechwładnie panuje idea przewagi liczby". Powołuje poglądy, że jest to propagowanie absolutyzmu państwowego, suwerenność narodu zaś jest tylko „odwróconą kopią francuskiego króla” ${ }^{35}$. Ten obszerny wywód zamyka jednak konkluzja o wymowie optymistycznej. Wykonywanie praw politycznych wymaga, aby każda jednostka rozumiała interesy i potrzeby publiczne i posiadała konieczny zmysł polityczny. „Najlepszą szkoła polityczna jest praktyczny wspótudziat w pracy w samorzadowych instytucjach" ${ }^{36}$. Konkluzja ta implikuje opisana w monografii Panejki koncepcję decentralizacji doskonale znaną, gdyż wielokrotnie opisywaną w kontekście sporu z Bigo o istotę samorządu terytorialnego.

Wcześniejsze i późniejsze próby odczytania poglądów Rousseau okazywały się niezwykle trudne i prowadziły do licznych i gwałtownych sporów ${ }^{37} . \mathrm{Z}$ jednej strony, świadczyło to ogromnej sile ich oddziaływania, z drugiej - ujawniało wieloznaczność i sprzeczności twierdzeń, wielokrotnie interpretowanych z perspektywy „późniejszych doświadczeń historycznych, których ani nie mógł przewidzieć, ani tym bardziej chcieć' ${ }^{38}$. Jakie zatem racje, na tle krytyki zawartej w tekście Panejki, przemawiaja za uznaniem, że Rousseau jest protagonista idei wolności? Nie stracił on z pola widzenia konieczności ograniczania władzy państwa, rozszerzając ponad miarę zakres obowiązywania zasady ogólnej woli; pisał, że „ze swej strony suwerenny lud nie może obarczać poddanych żadnym ciężarem niepotrzebnym wspólnocie"39. Wśród opinii wyrażanych w piśmiennictwie podkreśla się, że w teorii państwa Rousseau zawarte są niezbędne elementy gwarantujące wolność jednostki. Przy założeniu równości obywateli ograniczeniem władzy państwa jest to, że wola powszechna „dotyczy wszystkich obywateli i wszystkich tak samo" - trudno więc przyjąc, że ludzie będą tworzyć prawa dla siebie uciążliwe. „Prawo tworzy lud, wola

${ }^{34}$ Ibidem, s. 125.

35 Ibidem, s. 122.

36 Ibidem, s. 131-132.

37 U podstaw znalazł się spór o wpływ idei Rousseau na świadomość i postawy ludzi w toku Wielkiej Rewolucji Francuskiej. „Problem polega na tym, że dzieło Jana Jakuba po dziś dzień nie doczekało się jednolitej interpretacji, spór zaś o oddziaływanie jego idei jest tylko pochodną sporu o treści w nim zawarte”, M. Zmierczak, Jan Jakub Rousseau-rzecznik totalitaryzmu czy liberalnej demokracji?, „Czasopismo Prawno-Historyczne” 41, 1989, z. 2, s. 2.

38 Ibidem, s. 14.

${ }^{39}$ Cyt. za: N. Bobbio, op. cit., s. 6. „[...] przypisywanie mu ojcostwa »demokracji totalitarnej« to chwyt polemiczny tyle niefortunny co niepoprawny”, ibidem. 
powszechna, nie tworzy go siła, ale zgoda wszystkich" ${ }^{40}$. W tym też widział gwarancję wolności jednostki; uznawał, że najlepszą formą państwa jest demokracja - efekt umowy społecznej. Jednak idealizowane wyobrażenie kondycji ludzkiej dawało wyraz słabości podstawowego założenia umowy społecznej: „Gdyby istniał lud złożony z bogów, miałby rząd demokratyczny. Tak doskonały rząd nie nadaje się dla ludzi" ${ }^{41}$.

Wywód Panejki jest ciagle interesujacy, gdyż daje wyraz napięciu, dostrzeganemu we współczesnej literaturze; jest to napięcie, które niejako organicznie jest niesione ideą demokracji - idea otwarcia przestrzeni władzy dla ludzi, a zarazem, natychmiast, idea jej zabezpieczenia przed zagrożeniem, jakim sa ludzie, którzy z demokracji korzystaja. W sferze styku idei jako wartości oraz idei jako gwarancji ochrony tych wartości nieustannie pojawiają się zaskoczenia; żyjemy w nieustannym lęku o trwałość demokracji i ze świadomościa, że pod jej szyldem mogą powstać struktury władzy pozbawionej moralności (a więc zakłamanej) i nieobliczalnej - bez poczucia realizmu. Kilka następnych uwag tego opracowania będzie dotyczyć zjawisk w sferze styku z odniesieniem do samorządu terytorialnego.

Trudności związane z instytucjonalizacją władzy suwerennego Narodu pojawiły się tuż po ogłoszeniu Deklaracji praw człowieka i obywatela ${ }^{42}$. „Sprawa nie była jednak prosta, nowy suweren nie mógł zwyczajnie okryć się monarszym płaszczem, który zdjęto z ramion króla" ${ }^{43}$. Suwerenny lud musi składać się z obywateli-ustawodawców, musi wybrać wykonawców ustaw, musi ich skutecznie kontrolować. „Utopijność takiej koncepcji jest oczywista”. Ten model „demokracji czystej”, jak go określa Jan Baszkiewicz, wkrótce musi ustapić demokracji przedstawicielskiej - fundamentem władzy ludu staje się powszechne głosowanie, podstawa politycznej stabilizacji: „lud dysponujacy kartką wyborczą odłoży na bok karabin i pałkę" ${ }^{44}$. Ale to są ówcześnie wyidealizowane wyobrażenia, gdyż tylko demokrata uzna, że jeśli większość chce czegoś, to jest to wystarczająca podstawa „do uznania tego czegoś za dobre, [...] wola większości rozstrzyga nie tylko o tym, co jest prawem, lecz także o tym, co jest dobrym prawem”. Natomiast liberał, który akceptuje wolę większości, nie zakłada, że tylko dlatego musi to być dobre prawo ${ }^{45}$.

Demokracja przedstawicielska opiera się na przeświadczeniu, że wybrani przedstawiciele ludu będą lepiej rozumieć i chronić interes ogólny niż sami obywatele, pod tym wszakże warunkiem, że będzie to przedstawiciel narodu, a nie wyłącznie swych wyborców. A zatem powinna być wykluczona możliwość uzależnienia mandatu od wyborców; winien on być sprawowany bez żadnych

${ }^{40}$ M. Zmierczak, op. cit., s. 11.

${ }^{41}$ Cyt. za: N. Bobbio, op. cit., s. 21. M. Zmierczak podkreśla dążenie Rousseau do zapewnienia jednolitości myślenia i odczuwania obywateli, op. cit., s.15.

42 Art. 3 Deklaracji głosi: „Zasada całej suwerenności w swej istocie spoczywa w Narodzie. Żadne ciało ani żadna jednostka nie może wykonywać władzy niepochodzącej w sposób wyraźny od Narodu”, cyt. za: J. Baszkiewicz, Francja w Europie, Wrocław 2006, s. 106.

43 Ibidem.

${ }_{4}$ Ibidem, s. 112.

45 F. A. Hayek, Konstytucja wolności, Warszawa 2006, s. 112-113. 
warunków narzucanych interesami partykularnymi ${ }^{46}$. Pogląd taki wyraził również Trybunał Konstytucyjny w kwestii wyborów do organów stanowiących samorządu terytorialnego. Przepisy regulujące ustrój i prawo wyborcze „przyjmują ogólnie biorąc koncepcję mandatu wolnego, którego istotna cechą jest prawny dystans mandatariusza od jego wyborców". A zatem radny, po wyborach realizuje przede wszystkim interes publiczny, nie podlegając wprost woli wyborców ${ }^{47}$.

Pojawiający się tu dylemat rządów większości może być przynajmniej w części rozwikłany, jeśli uzna się zasadność liberalnego postulatu, aby wyznaczyć wyraźne granice rozstrzygania spraw głosami większości, pod warunkiem że działa ona na podstawie ustalonych zasad ogólnych, które - jak pisze Friedrich A. Hayek - tworzą ze zbiorowiska ludzi wspólnotę ${ }^{48}$. Władza nieograniczona prowadzi do „tyranii większości” lub dobrze znanej z praktyki ustrojów totalitarnych „tyranii w imieniu większości” (powołującej się zawsze na mandat ludu ${ }^{49}$. Społeczeństwo może bowiem samo sobie zagrażać; brak konstytucyjnych gwarancji ochrony praw jednostek i mniejszości przed interesami i namiętnościami większości może prowadzić do sytuacji, gdy „chwilowa większość może unieważnić prawa"50. Nieograniczone rządy większości w jej interesie „to nie tylko w poglądach Platona i Arystotelesa, lecz również twórców naszej konstytucji uznano”, że jest to wypaczona forma rządzenia, pisze John H. Hallowell ${ }^{51}$. Przejście od demokracji do tyranii jest według Platona procesem indywidualnej i społecznej dezintegracji. „Wolność, która stała się przyzwoleniem na wszystko, przekształca się w ciężar nie do zniesienia i ludzie chcą się od niej uwolnić, oddając się w ręce tyrana" "52. Upowszechniają się marzenia „o jedynej, opiekuńczej i wszechstronnej władzy, którą wybieraliby jednak wszyscy obywatele [...]. W systemie tym obywatele zrzucają zależ-

46 „Francuska konstytuanta, aby formalnie rozdzielić reprezentanta od reprezentowanych, za namową Siéyèsa wprowadziła do konstytucji z 1791 r. zakaz mandatu wiążącego" (art. 7, sekcja III, rozdz. I), cyt. za: N. Bobbio, op. cit., s. 23.

${ }^{47}$ M. Zubik (red.), Konstytucja III RP w tezach orzeczniczych Trybunału Konstytucyjnego $i$ wybranych squów, Warszawa 2008, s. 655 (875 K 24/97).

${ }^{48}$ Ibidem, s. 115. Myśl tę można odnaleźć także w dawnych, lecz nadal aktualnych wywodach o tyranii większości - władza zwierzchnia musi istnieć, lecz będzie zagrażać wolności, ,jeśli nie natrafi na żadne przeszkody, które by ją powstrzymywały i dawały jej w ten sposób czas na zastanowienie", A. de Tocqueville, O demokracji..., s. 192.

${ }^{49}$ H. Izdebski, Fundamenty..., s. 78. Nieustannie trzeba przypominaćocenyi wizje A. de Tocqueville’a, gdyż wbrew pozorom ich znajomość staje się przywilejem garstki wybranych: „Kiedy więc widzę, że jakiejś potędze zostaje przyznane prawo do wszechwładzy, to bez względu na to, czy nosi ona miano ludu czy króla [...], powiadam: "Oto zarodek tyranii«, i szukam sobie miejsca gdzie indziej”, idem, O demokracji..., s. 192.

50 Ustawę o nadzwyczajnych pełnomocnictwach z 23 marca 1933 r., która nadała pozór prawomocności nazistowskim rządom i późniejszym antyżydowskim ustawom norymberskim, uchwaliła większość deputowanych do niemieckiego Reichstagu, W. Osiatyński, op. cit., s. 130.

51 J. H. Hallowell, op. cit., s. 103.

52 Ibidem, s. 104. Jak pisze Platon: „Czy w pierwszych dniach i czasach nie będzie się uśmiechał do wszystkich i każdego uprzejmie witał, kogo tylko spotka, i będzie mówił nawet, że nie jest dyktatorem, a będzie przyrzekał wiele i prywatnie, i publicznie, będzie długi skreślał i ziemie rozdzielał ludowi i swoim najbliższym i czy nie będzie udawał łagodnego i łaskawego dla wszystkich”, cyt. za: J. H. Hallowell, op. cit., s. 105. 
ność tylko na chwilę, w której wybierają swego pana, po czym znów popadaja w niewolę" ${ }^{3}$. Warto więc pamiętać, że „Konstytucje zapewniają ochronę praw przed ustawodawca" ${ }^{54}$.

Przyjmuje się, dość powszechnie, że demokracja chroni ludzi przed nadużyciami władzy ${ }^{55}$. Zawsze przecież można odwołać się do demokratycznego systemu wyborczego i zmienić rząd. Jest to wiara dość naiwna ${ }^{56}$. Niebezpieczeństwa tkwią w strukturze demokracji wyborczej, której istotą jest opinia publiczna. Jaka jest podstawa informacyjna opinii publicznej - zadaje pytanie Giovanni Sartori. „Odpowiedź jest przytłaczająca, poparta stosami dowodów w podobnym duchu"57. Wśród zagrożeń wymienia: lekceważenie, brak zainteresowania, ignorancje „przeciętnego obywatela”; pod wieloma względami ludzie nie mają opinii, a raczej niewyraźne przeświadczenia ukształtowane pod wpływem nastrojów i zmieniających się uczućc ${ }^{58}$. A to potwierdza spostrzeżenie z połowy XIX stulecia: „Demokracja zresztą nie tylko nie może wybierać ludzi wartościowych, lecz również nie chce ich wybierać. [...] Stwierdzony jest fakt, że ludzie najbardziej wybitni są rzadko powoływani do pełnienia funkcji publicznych, i należy uznać, że zaczęło tak się dziać od chwili, gdy demokracja osiagnęła pełny rozwój”59. Demokracja zachęca ignorantów do wypowiadania stanowczych sądów o polityce (,typowy obywatel spada na niższy poziom mentalny, gdy tylko wkracza w dziedzinę polityki”60). Racjonalność narzucana przez sytuację międzynarodową lub ekonomiczną bardzo rzadko wywiera wpływ na kształtowanie obiegowych, upowszechnianych poglądów.

Znakomite analizy demokracji wyborczej Sartoriego trzeba uzupełnić charakterystyką demokracji nieliberalnych i populistycznych. Wspólną cechą tych „demokracji” jest wiara przywódców, że wyborcze zwycięstwo daje im nieograniczoną władzę, pisze Wiktor Osiatyński. Stąd próby ograniczenia lub likwidacji niezależnych instytucji, np. sądownictwa konstytucyjnego. Strach ma kluczowe znaczenie w demokracji populistycznej, podobnie jak w dyktaturze. „Różnica polega na tym, że dyktator mówi: "Bój się mnie, inaczej cię skrzywdzę», natomiast populistyczny przywódca mówi: "Bój się ich, a ja cię ocalę«". Polityczny populizm usprawiedliwia łamanie praw człowieka powoływaniem się na rzekomy „interes narodu”, zgodnie z preferencjami większości obywa-

${ }^{53}$ A. de Tocqueville, $O$ demokracji..., t. 2, Kraków 1996, s. 330.

${ }^{54}$ W. Osiatyński, op. cit., s. 130.

55 Ibidem. Nową koncepcję nadzoru we wspominanej tu reformie decentralizacyjnej we Francji uzasadniano koniecznością zabezpieczenia interesów samego samorządu, który, jak pisano z ironią, bywa „pierwszą ofiarą nieudolności zarządzania swych przedstawicieli”, M. Fromont, Les techniques de répartition des compétences entre l'Etat, les régions et les collecitvités locales, w: Les compétences des collectivités territoriales en matière d'urbanisme et d'équipement, sous la direction de M. Fromont, Paris-Bruxelles 1987, s. 282.

56 W. Osiatyński, op. cit., s. 164.

${ }_{57}$ G. Sartori, Teoria demokracji, Warszawa 1994, s. 136.

58 Ibidem.

59 A. de Tocqueville, $O$ demokracji..., t. 1, s. 156-157.

${ }^{60}$ Zdanie Josepha Schumpetera przytacza G. Sartori, op. cit., s. 140: „Astronom dyskutujacy o filozofii, chemik wydający sądy o muzyce lub poeta rozprawiający o matematyce nie wypowiedzą mniej nonsensów, niż przeciętny obywatel odpowiadający na pytania ankietera". W dziedzinie polityki jesteśmy zachęcani do przekraczania granic własnej niewiedzy, ibidem. 
teli $^{61}$. Instrumentem propagandy staje się rozbudzanie emocji; „narastajacy populizm odsuwa debatę publiczna jeszcze dalej od racjonalnej argumentacji ku symbolom, lękom i zagrożeniom" ${ }^{2}$. To współczesna droga zakłamywania demokracji - a zarazem mimowolnego odsłaniania jej słabości.

Od słabości demokracji przedstawicielskiej uwolnić może referendum swoista postać demokracji bezpośredniej. Jest to jednak postać pozbawiona bezpośredniości wzajemnych oddziaływań (demokracja „odizolowana”, jak ja określa Sartori). Poglądy uczestnika referendum nie są kształtowane przez dialog - podobnie jak uczestnika wyborów. Jest on biernym słuchaczem komentarzy podawanych przez środki masowego przekazu, z reguły niewdających się w dociekanie, kto ustalił treść i konkretne sformułowania kwestii podawanych w referendum. Można tu zauważyć, „że im większy obszar demokracji bezpośredniej, tym mniejsza jej autentyczność” ${ }^{63}$. Sartori rozróżnia opinię i wiedzę. „Wiedza pociaga za sobą przynajmniej ogarnięcie i umysłowe opanowanie informacji, czego sama informacja w żadnym razie nie zapewnia”. Wiedzę można powiązać z kompetencją. Dysponując tym samym zasobem informacji, ktoś może być kompetentny albo niekompetentny, zależnie od tego, czy trafnie dostrzega, jakie sa konsekwencje poszczególnych decyzji czy dzia$ł^{\prime}{ }^{64}$. Sartori podtrzymuje tezę, że informacja polityczna jest funkcją „wyższych poziomów wykształcenia, [...]. Można wszakże być bardzo wykształconym i pozostać politycznym analfabeta" ${ }^{65}$. Nie da się też wykluczyć sytuacji, gdy o kwestii dotyczacej jednej grupy społecznej w referendum rozstrzygnie ogół głosujących w znacznej lub w dominującej części indyferentnych, bez żadnej wiedzy praktycznej w danej dziedzinie.

Opisane zagrożenia demokracji mogą występować w różnej skali i z różnym natężeniem, mogą zatem dotyczyć demokracji przedstawicielskiej w samorządzie terytorialnym i determinować w sposób negatywny jego pozycję ustrojowa i działanie. Wynikać moga z przyczyn strukturalnych, a także być pochodna uwarunkowań zewnętrznych. Spośród wielu dysfunkcji opisanych w diagnozie w powołanym wyżej Raporcie o stanie samorzadności terytorialnej w Polsce, majacej fundamentalne znaczenie dla ukierunkowania reformy ustrojowej państwa, należy na wstępie zwrócić uwagę na dominację organów wykonawczych nad organami stanowiącymi (dysfunkcja autokratyczna) ${ }^{66}$.

Dysfunkcja autokratyczna ma charakter strukturalny i wynika z wprowadzenia w gminach w 2002 r. systemu prezydenckiego. System ten zablokował możliwości współdziałania organów gminy; w przypadku różnych opcji politycznych organu wykonawczego i większości rady konflikt, a nie kohabi-

61 W. Osiatyński, op. cit., s. 141.

${ }^{62}$ Ibidem, s. 145. Z kolei Ofer Raban podkreśla, że ucieczka od racjonalności w dyskusji politycznej osłabia lub unicestwia zasadę rządów prawa (nie tylko w kształtowaniu działalności ustawodawczej, ale także w interpretacji prawa), idem, op. cit., s. 36 i n.

${ }^{63}$ G. Sartori, op. cit., s. 147.

64 Ibidem, s. 153.

65 Ibidem, s. 139.

${ }_{66}$ Narastajace dysfunkcje..., t. 1, s. 28 i n. Znaczenie Raportu jest porównywalne z przełomowym znaczeniem, jakie dla wielkiej reformy decentralizacyjnej we Francji miało opracowanie Oliviera Guicharda, Vivre ensemble z 1976 r. 
tacja, staje się reguła. „Dramatycznie została zdeprecjonowana pozycja rad gmin i samych radnych jako "narzędzi« kontrolnych nad gminnymi zarządami i urzędnikami”. Merytoryczna dominacja urzędników nie jest konfrontowana ze stanowiskiem radnych, wspomaganych ekspertyzami, gdyż radni nie maja pieniędzy na angażowanie ekspertów. Osłabiany jest też udział rad w tworzeniu projektów prawa miejscowego, gdyż w praktyce rada gminy nie ma instrumentów, które mogłyby nakłaniać organy wykonawcze do realizacji jej uchwał ${ }^{67}$. Inną nieco dysfunkcja jest brak ograniczenia kadencyjności władzy wykonawczej; w myśl Raportu to „oczywista, praktyczna i fundamentalna niespójność z modelem prezydenckim”. „Współczynnik dominacji” urzędujących prezydentów ilustruje m.in. zachwianie jednego z kanonów demokracji, jakim jest zdolność podjęcia rywalizacji ${ }^{68}$. O ile jednak jest uzasadniona kontynuacja funkcji dobrze ocenianego prezydenta dużego miasta, o tyle trzeba pamiętać, „że możliwe sa kolejne reelekcje władzy w źle rządzonych gminach”. W środowisku niewielkiej zwłaszcza gminy, w swoim bliskim otoczeniu wójt jest wybierany wielokrotnie, umiejętnie wykorzystując zasoby, którymi rozporządza. Jest to rodzaj sytuacji, która eliminuje rzeczywistych kontrkandydatów ${ }^{69}$.

Rozpatrywana w szerszej płaszczyźnie preferencja modelu prezydenckiego jest świadectwem swoistego sporu cywilizacyjnego - między orientacja wiążąca samorząd strukturalnie $\mathrm{z}$ hierarchiczną administracją państwa a orientacja cywilizacyjną Europy Zachodniej z głęboką tradycją demokracji przedstawicielskiej, również na poziomie lokalnym ${ }^{70}$. Można uznać za paradoks, że formuła kohabitacji została wypracowana w ojczyźnie pierwszej w Europie decentralizacji, która niemal natychmiast zastapiona konsekwentną i rygorystyczną centralizacją nie zatraciła idei służby Republice i potrafiła ją chronić przez następne dwa stulecia.

Obszerny zespół problemów wynika z udziału partii politycznych w funkcjonowaniu demokracji lokalnej. Upartyjnienie administracji jest uznawane za jedno z największych zagrożeń dla państwa i społeczeństwa ${ }^{71}$. Rażącym następstwem upartyjnienia administracji publicznej jest zatarcie granicy między sfera działalności politycznej i administracyjnej. „Jednak przekazanie władzy danej partii nie oznacza, że uzyskała ona prawo do decydowania o wszelkich sprawach administracyjnych". Indywidualne prawa obywateli powinny być szanowane; narażone na koniunkturalne wpływy polityczne świadczą o ograniczaniu wolności. Konieczność wyłączenia administracji spod politycznych nacisków jest podstawą postulatów, aby tworzyć, stabilizować i chronić kadry urzędników profesjonalnych i politycznie neutralnych ${ }^{72}$. Partyjność, która wdarła się do samorządu terytorialnego w Polsce jest dysfunkcją osłabiajacą więzi wspólnotowe, prowadzi do degeneracji pojęcia interesu publicznego i wypaczenia procedury wyborczej. Polityka kadrowa podporządkowana inte-

${ }^{67}$ Narastajace dysfunkcje..., t. 1, s. 29.

${ }^{68}$ Ibidem, s. 30.

69 Ibidem.

70 J. Stępień, Cywilizacyjny spór..., s. 21.

71 Samorzad i demokracja lokalna..., s. 9.

72 „Skutki zbyt częstej praktyki obsadzania ignorantami stanowisk wymagających wysokich kwalifikacji urzędniczych są opłakane. Przykładów można przytoczyć wiele”, ibidem. 
resom partii lub lokalnych grup nacisku prowadzi do zaniku siły oddziaływania opinii publicznej. Nie budzi sprzeciwu oświadczenie prezydenta miasta, że za swoją działalność odpowiada przed partią. Partia niejednokrotnie decyduje o pozostawieniu na stanowisku nieudolnego urzędnika; o tym, czy pijany starosta może nadal pełnić swój urząd, przesądzają układy polityczne, bez względu na osąd opinii publicznej. „Dziś wiadomość, że ktoś jest złodziejem, nie oznacza, że zostanie on potępiony przez lokalna społeczność”’ ${ }^{\prime 3}$. Znacznym obciążeniem w tworzeniu klimatu wspólnotowego w wymiarze lokalnym jest brak podstawowej wiedzy politycznej wśród elit lokalnych, radni na ogół nie sa zainteresowani jej podnoszeniem ${ }^{74}$.

Kreowane przez partie liczne lokalne komitety wyborcze (stowarzyszeń, organizacji społecznych) są atrapami kryjącymi forsowanie interesów partyjnych. Następuje utrwalanie „w samorządach wpływów krajowych partii politycznych, a co istotniejsze, do ograniczania przestrzeni dla autentycznych, społecznych komitetów wyborczych, które sa zmuszane do uczestnictwa w nierównej rywalizacji z reprezentacjami silnych partii politycznych"75.

Powołane tu raporty otwieraja szeroka panoramę dysfunkcji, czy wręcz nadużyć. Przede wszystkim jednak wskazują warianty rozwiązań i drogi wyjścia z piętrzących się zagrożeń dla demokracji lokalnej. Te zalecane konieczne działania potwierdzaja pogląd, że idea demokracji jest fundamentalnym składnikiem samorządu w wolnym społeczeństwie; jest to zarazem idea wymagająca nieustannej uwagi i zabezpieczeń - wobec immanentnych słabości, a także zewnętrznych dążeń do jej instrumentalizacji.

prof. dr hab. Jan Jeżewski

Wyższa Szkoła Zarządzania i Finansów w Warszawie,

em. profesor Uniwersytetu Wroctawskiego

janjez@prawo.uni.wroc.pl

\section{THE IDEA OF DEMOCRACY IN SYSTEMIC TRANSFORMATIONS OF SELF-GOVERNMENT}

Sum mary

The article aims to show the idea of democracy as a basic condition for implementing decentralisation and self-government. At the same time it identifies certain threats that accompany those processes and the need for their protection.

Democracy, understood both as a value and a principle, constitutes, together with the principles of freedom and the state of law, one of the basic axiological and system standards in modern Europe. Attempts at defining democracy made within the scientific domain of particular states manifest themselves in various ways; as a result, there are numerous definitions of the principle of democracy and of a democratic state itself. However, the variety of perspectives does not reduce the influence of the idea of democracy and, especially, its inspirational effect. In the state of law, democracy protects all the rights and freedoms of an individual connected with political liberalism. Since 1789 and the Declaration of the Rights of Man and of the Citizen, the notion of decen-

\footnotetext{
73 Ibidem, s. 11.

74 Ibidem, s. 10.

${ }^{75}$ Narastajace dysfunkcje..., t. 1, s. 32.
} 
tralisation has been developing in Europe. This has taken place together with consolidation of the belief that democracy is a condition of decentralisation and self-government is an institutional form of participation by citizens in governance, serving the bottom-up development of democracy. This has been reflected in the concept of local democracy, most often, in connection with the process of systemic change: as a positive effect of these transformations or as an objective (value) which should be pursued in future reforms. The article also indicates immanent weaknesses of democratic procedures that can be used opportunistically and for purposes far removed from the idea of democracy. Local democracy is threatened by the political indifference of voters, the tyranny of the majority, populism and a ruling party's control over self-government. 